\title{
LIPID PROFILE AND BODY COMPOSITION OF HIV-1 INFECTED PATIENTS TREATED WITH HIGHLY ACTIVE ANTIRETROVIRAL THERAPY
}

\author{
PONTES L. C. R. (1), CARVALHO L. R. (2), SOUZA L. R. (1),
} TRINDADE E. B. S. M. (1), PEREIRA P. C. M. (1)

(1) Department of Tropical Diseases, Botucatu School of Medicine, São Paulo State University (UNESP), Botucatu, São Paulo, Brazil; (2) Department of Biostatistics, São Paulo State University (UNESP), Botucatu, São Paulo, Brazil.

ABSTRACT: Highly active antiretroviral therapy (HAART) has been associated with the development of a clinical group and metabolic disorders such as peripheral lipodystrophy syndrome in AIDS. The aim of this study was to analyze the lipid profile, the clinical aspects, and the body composition of HIV-1 infected individuals treated with or without protease inhibitor (PI) during the highly active antiretroviral therapy. In total, 62 individuals were evaluated in this study; 15 healthy individuals (Control Group: CG), 11 HIV-1 infected individuals treated without antiretroviral therapy (Group 1: G1), 14 HIV-1 infected individuals treated with antiretroviral therapy plus protease inhibitor (Group 2: G2), and 22 HIV-1 infected individuals treated with antiretroviral therapy without protease inhibitor (Group 3: G3), mean age 35 years old. The time interval for G2 and G3 was greater than or equal to nine months. Patients receiving HAART with PI had significantly lower viral loads, hypertriglyceridemia, and low HDL levels $(p<0.05)$. There were no differences between groups in relation to the lean body mass percentage obtained by mid-arm muscle circumference adequacy or by bioelectrical impedance. The lower percentage of body fat observed in all the HIV-1 infected patients by antropometric assessment and the decreased tricipital skinfold adequacy in the group treated with PI in relation to CG may suggest lipodystrophy in the upper limbs, especially on those treated with PI.

KEY WORDS: lipodystrophy, HIV-1, highly active antiretroviral therapy, dyslipidemia, hypertriglyceridemia.

CORRESPONDENCE TO: L. C. R. PONTES, Departamento de Doenças Tropicais e Diagnóstico por Imagem, Faculdade de Medicina de Botucatu, UNESP, Distrito de Rubião Júnior, s/n, 18618-000, Botucatu, SP, Brasil. Email: lizzye pontes@yahoo.com 


\section{INTRODUCTION}

The widespread utilization of highly active antiretroviral therapy (HAART) has led to a sustained reduction in the morbidity and mortality associated with HIV-1 infection (26, $30)$. On the other hand, HAART has a variety of adverse side effects $(7,8,9)$ that can develop into a new clinical and laboratorial syndrome known as lipodystrophy (LD) syndrome.

The main manifestations of the LD syndrome in patients with normal serum cortisol levels are fat accumulation in the dorsocervical spine (also known as buffalo hump), in the breasts, and in the abdomen, or fat reduction in the face and in the limbs. Lipoatrophy may occur isolated or together with fat accumulation. It was reported in some patients that these body changes are accompanied by metabolic disorders and dyslipidemia, resulting in serum levels alterations, including glucose, triglycerides, and cholesterol $(6,9,35)$. LD has been associated with HAART with protease inhibitor (PI); however, there are reports of hyperlidemia and lipodystrophy associated with HAART without PI $(22,34,38)$. Metabolic disorders, which include disturbances in the lipid metabolism and increases in the serum level of triglycerides and cholesterol, have been observed in all stages of the HIV-1 infection $(3,28,31,32)$. A recent study by Smith et al. demonstrated an excess of cardiovascular risk factors in HIV patients receiving HAART (37).

There are many reports and studies that have noted variations in the presence of lipodystophy among HIV-1 infected patients treated with PI. These reports have observed a difference between $0.1 \%$ and $64 \%(4,5,9,42)$. The highest LD prevalence associated with HIV-1 infected patients treated with PI was reported by Carr et al. (11), who observed $80 \%$ of the patients with LD syndrome. In another study, Gerrior et al. (21) reported that from 39 patients with LD, 10\% had never been treated with PI. In a published study comparing 96 HIV-1 infected individuals, it was reported that the abnormalities in fat distribution are characteristics of the HIV-1 infection, independent of the treatment (24).

In another study, Boufassa et al. (5) reported that the average serum cholesterol levels as well as the serum triglyceride levels were higher among patients treated with PI in comparison to the patients not treated with PI. Another aspect related to LD reported is 
the association between the HIV-1 infection and the duration of treatment with or without PI ranging from 7 to 22 months (3).

Recently, metabolic disorders with decrease in the serum high-density lipoprotein (HDL) cholesterol levels have been observed in HIV-1 infected patients; a decrease in HDL has also been associated with an increase in the cardiovascular risk (29).

Although the use of HAART has allowed changes in the prognostic, the quality of health and the morbidity of many HIV-1 infected patients, the development of LD, and dyslipidemia have been considered a very worrisome factor. There is a need to know if these new drugs are affecting the lipid profile of such individuals, therefore our objective is to evaluate the effectiveness of using HAARTs in HIV-1 infected individuals. This study was performed to analyze the lipid profile, the clinical and nutritional aspects of HIV-1 infected individuals during treatment with or without HAARTs in the region of Botucatu, São Paulo, Brazil.

\section{PATIENTS and Methods}

\section{Patients}

From November 2000 to May 2001, 62 individuals between 19-53 years, including 27 females and 35 males, were studied. From this total, 47 (76\%) were HIV-1 infected outpatients from the Infectious and Parasitary Disease Area of Botucatu School of Medicine, UNESP, and 15 (24\%) were healthy blood donors from the Blood Bank Center of Botucatu School of Medicine, UNESP. All the patients were organized in the following study groups: Control Group (CG), consisted of 15 healthy blood donors, ranging in age from 23 to 53 years old ( $\bar{x} 34 \pm$ SD 8.8); Group 1 (G1), consisted of 11 HIV-1 infected patients, ranging in age from 19 to 46 years ( $\bar{x} 35 \pm$ SD 9.2), who did not receive HAART; Group 2 (G2), consisted of 14 HIV-1 infected patients, ranging in age from 24 to 48 years ( $\bar{x} 38 \pm$ SD 7.0), who received HAART with PI for time interval greater than or equal to nine months; Group 3 (G3), consisted of 22 HIV-1 infected patients, ranging in age from 25 to 45 years ( $\bar{x} 34 \pm$ SD 6.3), who received HAART without PI for time interval greater than or equal to nine months. 


\section{Body composition}

Anthropometric assessment included weight/height ${ }^{2}$ for Body Mass Index (BMI) measurements; skinfold thickness measured at four sites (subscapular, bicipital, tricipital, and suprailiac areas), taken at the non-dominant side; upper arm circumference; and upper mid-arm muscle circumference (MAMC) calculated from the formula: MAMC $(\mathrm{cm})=$ mid-arm circumference $-(0.314 \times$ triceps skinfold $[\mathrm{mm}])(12,15$, $19,39)$. MAMC adequacy in percentage was calculated using the formula: MAMC obtained $(\mathrm{cm}) / 50$ percentil MAMC $\times 100$ of each patient, according to the age and gender $(19,20)$. Tricipital skinfold (TSF) thickness adequacy in percentage was obtained using the formula: TSF obtained $(\mathrm{mm}) / 50$ percentil TSF $\times 100$ of each patient, according to the age and gender $(19,20)$. Body fat percentage (BFP) was estimated from the anthropometric assessment using the equations of Durnin and Womersley (1974) by the sum of subscapular, bicipital, tricipital, and suprailiac skinfold, according to the age and gender $(14,15)$. Total body fat percentage adequacy was obtained using the formula: BFP obtained/50 percentil BFP $\times 100$ of each patient, according to the age and gender $(19,20)$. BMI adequacy in percentage was calculated using BMI/21.7×100, where 21.7 is the mean of 18.5 and 24.9 , the range for eutrophic individuals according to the World Health Organization, 1995 and 1997. All the anthropometry measurements were performed by the same method (21) three times and averaged. Lange skin fold caliper (Cambridge Scientific Industries, Cambridge, Massachusetts, USA) was used to assess the skinfold measurement.

\section{Bioelectrical impedance}

After 8 to 12 hours overnight fasting, bioelectrical impedance analysis (BIA) was used as a technique to assess the nutritional status and body composition in the individuals of each group. BIA measurements were done by the same method, using standard electrode positions (36). Whole-body bioelectrical impedance was measured with Comp Corp ${ }^{\circledR}$ Version 2.5, and the reactance and resistance values were analyzed with the Corp ${ }^{\circledR}$ program estimating the lean body mass (LBM), the total body water (TBW), and the body fat mass (BFM) percentage.

\section{Clinical-Epidemiological Aspects}


The following clinical-epidemiological aspects were analyzed during patient visits: HIV-1 infection duration, age, race, gender, cigarette smoking ( $>5$ cigarettes/day), alcohol consumption ( $>80 \mathrm{~g} /$ day), sedentary life style $(<1 \mathrm{~h} /$ week of sport activity), diarrhea $(>2$ liquid evacuations $>2$ days), weight loss ( $>5 \%$ of total body weight), any episode of fever, anorexia and vomiting in the last two months. Patients were asked to describe any body shape changes observed during care for HIV-1 and lipoatrophy in the upper and lower limbs, and the face; accumulation of fat in the dorsocervical fat pad, breast enlargement, and fat accumulation in the abdomen were then analyzed based on the patients' self-report interview.

\section{Laboratory assays}

Hematological, biochemical and immunologic assays were carried out. After 8 to 12 hours overnight fasting, venous blood samples were collected and analyzed. These samples were analyzed in the Clinic Laboratories of Botucatu School of Medicine UNESP. The hematological evaluation was characterized by hematocrit (Hct) and hemoglobin $(\mathrm{Hb})$ by the photometric approach using the device CELL-DYN ${ }^{\circledR} 3500$ System Abbott. The serum biochemical evaluation was performed for triglyceride (TG) (18), glucose, albumin (13), total cholesterol (TC) (1), high density lipoprotein (HDL) cholesterol (40), and low density lipoprotein (LDL) cholesterol LDL was calculated by the Friedewald method, except in patients with TG levels $>400 \mathrm{mg} / \mathrm{dL}$ (LDL $=$ total cholesterol - ([TG/5] + HDL cholesterol). Quantitative determination of both T CD4+ and CD8+ lymphocyte counts was carried out by the flow cytometer "Cyto-ulter Clone ${ }^{\circledR}$. CD3 (IgG1)-FIT/T4-RD1 by Cyto-Stat ${ }^{\circledR} /$ Coulter Clone ${ }^{\circledR}$. CD3 (IgG1)-FIT/T8-RD1 and HIV-1 viral load by the kit "Nuclisens TM HIV-1/QT NASBA DIAGNOSTICS" - ORGANON TEKNIKA techniques in the HIV-1 infected individuals were used to assess the immunological activity.

\section{Statistical analysis}

A power of $80 \%$ was considered with a $5 \%$ significant level, taking into consideration the average values and standard deviation in the literature with reference to the variables: cholesterol, triglyceride, and albumin. Comparison of qualitative variables was 
determined using the Fisher's exact test. The Analysis of Variance (ANOVA) was used to determine quantitative variables with normal distribution, followed by the Tukey's multiple comparisons test to compare the means between groups. Kruskal-Wallis followed by multiple comparisons test was used to compare the non-parametric distribution (16). Probability levels of 0.05 or less were considered significant. The Ethical Committee of the Clinic Hospital, Botucatu School of Medicine, UNESP - São Paulo State University, approved the research protocol and an informed consent was obtained from all of the patients.

\section{RESULTS}

Table 1 shows that none of the groups presented differences with respect to gender, age, race, sedentary life style, fever, and weight lost ( $p>0.05$ ), neither G2 or G3 with respect to infection duration and transmission mechanism, although the male gender was predominant in all the groups. CG and G2 had significantly lower number of individuals that used to consume alcohol (>80g/day). G2 had more cigarette smokers than CG $(p<0.05)$ and more individuals with diarrhea than any other group. Vomiting was observed in higher proportion in $G 1$ and $G 2$ compared to $C G$ and $G 3(p<0.05)$, as shown in Table 1. There were no significant differences, as seen in Table 2, between the studied groups when the following were considered: accumulation of fat in the dorsocervical fat pad and in the breast, enlargement of the abdomen, and lipoatrophy in the face in HIV-1 infected individuals ( $p>0.05$ ). However, G2 and G3 had significantly lower fat in the upper and lower limbs than $G 1 \quad(p<0.05)$, Table 2. Though without statistical differences between them ( $p>0.05), \mathrm{T} \mathrm{CD}_{4}{ }^{+}$and $\mathrm{CD}_{8}{ }^{+}$counts were lower in all the HIV-1 infected groups. Analysis of the viral load, in Table 3, was higher in all the HIV-1 infected groups, however there was a significant difference $(p<0.05)$ only between individuals (G1) not treated with HAART and those treated with HAART plus PI (G2), shown in Table 3. There were significant differences between groups in relation to the glucose and albumin levels, although within normal limits. G2 had increased triglyceride levels in relation to $G 1$ and above the normal levels $(p<0.05)$; nonetheless there were no differences from the other groups. Cholesterol and LDL levels were normal and there were no differences between the groups studied ( $p>0.05)$. HDL, hematocrit, and hemoglobin from both genders did not differ between groups ( $p>0.05)$, but the HDL 
levels were below the normal levels in HIV-1 infected males and females (Table 3). In relation to anthropometry parameters, shown in Table 4, MAMC percentage was similar among all the study groups; BMI percentage was higher in $G 2$ in relation to $G 1(p<0.05)$; TSF percentage was significantly lower in $G 2$ than in CG $(p<0.05)$; and all the other groups presented lower BFP adequacy in relation to CG. BIA analysis of the body water, fat free mass, and total body fat percentage showed that all groups, including the control group, had no difference, as shown in Table 5.

Table 1. Distribution of the 62 subjects, HIV-1 infected or not, according to the presence of clinical-epidemiological parameters.

CG: Control group, blood donors

G1: HIV-1 ${ }^{+}$individuals, without HAART

\begin{tabular}{|c|c|c|c|c|c|c|c|}
\hline & CG & G1 & G2 & G3 & Total & Significance & Comments \\
\hline Parameters & $\mathrm{N}$ & $\mathrm{N}$ & $\mathrm{N}$ & $\mathrm{N}$ & $\mathrm{N}$ & & \\
\hline $\begin{array}{l}\text { Alcohol } \\
\text { consumption* }\end{array}$ & - & 5 & 1 & 7 & 13 & $p<0.05$ & $(C G=G 2)<(G 1=G 3)$ \\
\hline $\begin{array}{l}\text { Cigarette } \\
\text { Smoking }\end{array}$ & 3 & 6 & 10 & 12 & 31 & $p<0.05$ & $\begin{array}{c}C G<G 2 \\
C G=G 1=G 3\end{array}$ \\
\hline $\begin{array}{l}\text { Sedentary } \\
\text { life style* }\end{array}$ & 10 & 10 & 11 & 15 & 36 & $p>0.05$ & $C G=G 1=G 2=G 3$ \\
\hline Fever & - & 2 & 2 & 3 & 7 & $p>0.05$ & $\mathrm{CG}=\mathrm{G} 1=\mathrm{G} 2=\mathrm{G} 3$ \\
\hline Weight loss & 3 & 5 & 7 & 9 & 24 & $p>0.05$ & $\mathrm{CG}=\mathrm{G} 1=\mathrm{G} 2=\mathrm{G} 3$ \\
\hline Vomiting & - & 2 & 3 & - & 5 & $p<0.05$ & $(C G=G 3)<(G 1=G 2)$ \\
\hline Diarrhea & - & - & 5 & 1 & 6 & $p<0.05$ & $\mathrm{CG}=\mathrm{G} 1=\mathrm{G} 3<\mathrm{G} 2$ \\
\hline Anorexia & - & 3 & 4 & 5 & 12 & $p>0.05$ & $\mathrm{CG}=\mathrm{G} 1=\mathrm{G} 2=\mathrm{G} 3$ \\
\hline
\end{tabular}

G2: HIV-1 ${ }^{+}$individuals, with HAART and PI

G3: HIV $-1^{+}$individuals, with HAART and without PI

-: Numeric value is equal zero

*: one patient was not interviewed 
Table 2. Distribution of the $45^{\star} \mathrm{HIV}-1$ infected subjects, according to the study group, the presence of dorsocervical, abdominal and breast ${ }^{\dagger}$ fat accumulation and the presence of lipoatrophy in the face, upper and lower limbs.

\begin{tabular}{l|cccccc}
\hline \multirow{4}{*}{ Fat } & $\mathrm{G} 1$ & $\mathrm{G} 2$ & $\mathrm{G} 3$ & Total & Significance & Comments \\
\cline { 2 - 5 } & $(\mathrm{n}=10)$ & $(\mathrm{n}=13)$ & $(\mathrm{n}=22)$ & $(\mathrm{n}=45)$ & & \\
\cline { 2 - 5 } & $\mathrm{N}$ & $\mathrm{N}$ & $\mathrm{N}$ & $\mathrm{N}$ & & \\
\hline Hipertrophy & & & & & & \\
dorsocervical & - & 3 & 4 & 7 & $\mathrm{p}>0.05$ & $\mathrm{G} 1=\mathrm{G} 2=\mathrm{G} 3$ \\
Abdominal & 2 & 6 & 13 & 21 & $\mathrm{p}>0.05$ & $\mathrm{G} 1=\mathrm{G} 2=\mathrm{G} 3$ \\
Breast $^{\dagger}$ & 1 & 3 & 3 & 7 & $\mathrm{p}>0.05$ & $\mathrm{G} 1=\mathrm{G} 2=\mathrm{G} 3$ \\
Atrophy & & & & & & \\
Face & - & 4 & 4 & 8 & $\mathrm{p}>0.05$ & $\mathrm{G} 1=\mathrm{G} 2=\mathrm{G} 3$ \\
Limbs & 1 & 12 & 12 & 25 & $\mathrm{p}<0.05$ & $\mathrm{G} 1<\mathrm{G} 2=\mathrm{G} 3$ \\
\hline
\end{tabular}

G1: HIV-1 ${ }^{+}$individuals, without HAART

G2: HIV-1 ${ }^{+}$individuals, with HAART and PI

G3: HIV $-1^{+}$individuals, with HAART and without PI

-: Numeric value is equal zero

*: 2 patients were not interviewed

${ }^{\dagger}$ : women 
Table 3. Mean $(\bar{x})$ and standard deviation (SD) of the serum parameters and viral load (copies/ml) in logarithm of the 62 subjects, HIV-1 infected or not, according to the study group.

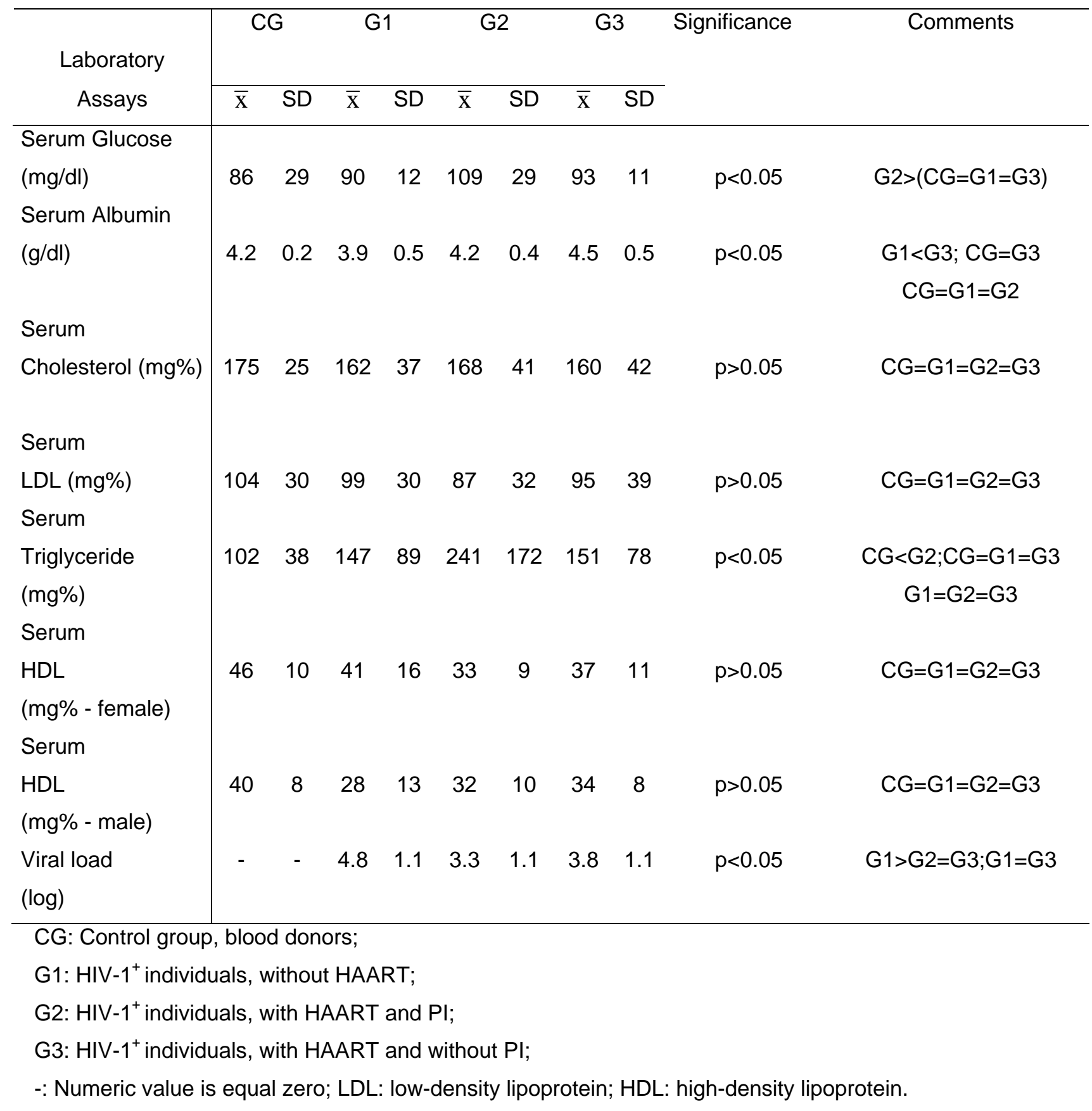


Table 4. Means $(\bar{x})$ and standard deviation (SD) of percentage adequacy of anthropometric parameters of the 62 subjects, HIV-1 infected or not, according to the study group.

\begin{tabular}{|c|c|c|c|c|c|c|c|c|c|c|}
\hline \multirow{2}{*}{$\begin{array}{c}\text { Anthropometric } \\
\text { Parameters }\end{array}$} & \multicolumn{2}{|c|}{$\begin{array}{c}\text { CG } \\
(n=15)\end{array}$} & \multicolumn{2}{|c|}{$\begin{array}{c}\text { G1 } \\
(n=11)\end{array}$} & \multicolumn{2}{|c|}{$\begin{array}{c}G 2 \\
(n=14)\end{array}$} & \multicolumn{2}{|c|}{$\begin{array}{c}G 3 \\
(n=22)\end{array}$} & \multirow[t]{2}{*}{$\begin{array}{l}\text { Signifi } \\
\text { cance }\end{array}$} & \multirow[t]{2}{*}{ Comments } \\
\hline & $\overline{\mathrm{x}}$ & SD & $\overline{\mathrm{x}}$ & SD & $\overline{\mathrm{x}}$ & SD & $\overline{\mathrm{x}}$ & SD & & \\
\hline \multirow[t]{3}{*}{ BMI \% } & 114 & 14 & 101 & 13 & 118 & 15 & 111 & 14 & $p<0.05$ & $G 2>G 1$ \\
\hline & & & & & & & & & & $\mathrm{GC}=\mathrm{G} 1=\mathrm{G} 3$ \\
\hline & & & & & & & & & & $\mathrm{GC}=\mathrm{G} 2=\mathrm{G} 3$ \\
\hline \multirow[t]{3}{*}{ TSF \%* } & 138 & 42 & 106 & 60 & 92 & 27 & 102 & 31 & $p<0.05$ & $\mathrm{GC}>\mathrm{G} 2$ \\
\hline & & & & & & & & & & $\mathrm{GC}=\mathrm{G} 1=\mathrm{G} 3$ \\
\hline & & & & & & & & & & $\mathrm{G} 1=\mathrm{G} 2=\mathrm{G} 3$ \\
\hline MAMC \%* & 94 & 12 & 87 & 10 & 97 & 10 & 95 & 14 & $p>0.05$ & $\mathrm{CG}=\mathrm{G} 1=\mathrm{G} 2=\mathrm{G} 3$ \\
\hline BFP \%\# & 115 & 16 & 92 & 22 & 98 & 10 & 100 & 11 & $p<0.05$ & $\mathrm{GC}>\mathrm{G} 1=\mathrm{G} 2=\mathrm{G} 3$ \\
\hline
\end{tabular}

CG: Control group, blood donors;

G1: HIV-1 ${ }^{+}$individuals, without HAART;

G2: HIV-1 ${ }^{+}$individuals, with HAART and PI;

G3: HIV-1 ${ }^{+}$individuals, with HAART and without PI;

BMI: Body Mass Index, TSF: Tricipital skinfold, MAMC: Mid-arm muscle circumference, BFP: Body fat percentage.

BMI adequacy was adapted according to the World Health Organization; TSF\% was adapted according to Frisacho AR. Anthropometric standards for the assessment of growth and nutritional status. Ann Arbor: University of Michigan Press, 1990; MAMC adequacy was adapted according to Blackburn, G. L. \& Thornton, P.A., 1979; Body fat percentage adequacy was adapted according to Frisacho AR. Anthropometric standards for the assessment of growth and nutritional status. Ann Arbor: University of Michigan Press, 1990.

*: one patient from $\mathrm{G} 2$ and one from $\mathrm{G} 3$ were not assessed.

\#: two patients from $\mathrm{G} 2$ and two from $\mathrm{G} 3$ were not assessed. 
Table 5. Mean $(\bar{x})$ and standard deviation (SD) of the bioelectrical impedance analysis (BIA) of the 62 subjects, HIV-1 infected or not, according to the study group and sex.

\begin{tabular}{|c|c|c|c|c|c|c|c|c|c|c|}
\hline \multirow{2}{*}{$\mathrm{BIA}$} & \multicolumn{2}{|c|}{ CG } & \multicolumn{2}{|c|}{ G1 } & \multicolumn{2}{|c|}{ G2 } & \multicolumn{2}{|c|}{ G3 } & \multirow[t]{2}{*}{ Significance } & \multirow[t]{2}{*}{ Comment } \\
\hline & $\overline{\mathrm{X}}$ & SD & $\overline{\mathrm{X}}$ & SD & $\overline{\mathrm{X}}$ & SD & $\overline{\mathrm{x}}$ & SD & & \\
\hline Female & & & & & & & & & & \\
\hline Water (\%) & 52 & 4 & 55 & 6 & 54 & 4 & 53 & 5 & $p>0.05$ & $\mathrm{CG}=\mathrm{G} 1=\mathrm{G} 2=\mathrm{G} 3$ \\
\hline Lean mass & & & & & & & & & & \\
\hline$(\%)$ & 71 & 5 & 74 & 7 & 73 & 5 & 73 & 7 & $p>0.05$ & $\mathrm{CG}=\mathrm{G} 1=\mathrm{G} 2=\mathrm{G} 3$ \\
\hline Fat mass & & & & & & & & & & \\
\hline$(\%)$ & 30 & 5 & 26 & 7 & 27 & 5 & 28 & 7 & $p>0.05$ & $\mathrm{CG}=\mathrm{G} 1=\mathrm{G} 2=\mathrm{G} 3$ \\
\hline Male & & & & & & & & & & \\
\hline Water (\%) & 61 & 6 & 65 & 7 & 60 & 5 & 60 & 6 & $p>0.05$ & $\mathrm{CG}=\mathrm{G} 1=\mathrm{G} 2=\mathrm{G} 3$ \\
\hline Lean mass & & & & & & & & & & \\
\hline$(\%)$ & 83 & 6 & 85 & 6 & 82 & 6 & 79 & 10 & $p>0.05$ & $\mathrm{CG}=\mathrm{G} 1=\mathrm{G} 2=\mathrm{G} 3$ \\
\hline Fat mass & & & & & & & & & & \\
\hline$(\%)$ & 17 & 6 & 15 & 5 & 18 & 6 & 21 & 10 & $p>0.05$ & $C G=G 1=G 2=G 3$ \\
\hline
\end{tabular}

CG: Control group, blood donors;

G1: HIV-1 ${ }^{+}$individuals, without HAART;

G2: HIV-1 ${ }^{+}$individuals, with HAART and PI;

G3: HIV $-1^{+}$individuals, with HAART and without PI.

\section{DISCUSSION}

Although there are significant studies about lipodystrophy $(3,10,21,29,42)$, its fat accumulation etiology is still uncertain in HIV-1 infected individuals. Some recent studies have shown a strong association between PI use and lipodystrophy (9), however many reports have been done on these alterations in patients treated with HAART without PI $(28,34)$. In addition, many factors not related to drugs may be associated to a higher risk of developing these body changes, such as gender, age, race, and HIV-1 infection duration, among others $(24,27,28)$. Although in this work we did not observe differences between the groups in relation to these variables. Protein energy malnutrition was not observed in any of the HIV-1 infected patients; being all of them 
eutrophic, which showed a recent change in relation to the pre-HAART era, when malnutrition was frequent (23). Only G1, constituted of HIV-1 positive patients, presented decreased BMI percentage in relation to the group treated with HAART plus $\mathrm{PI}$, probably because this group had not started HIV-1 therapy, consequently living the impact of HIV-1 infection on their nutritional status. Fat atrophy in the upper and lower limbs, evaluated by the patient's self report, was significantly higher in the patients in treatment. Abdominal fat accumulation, also evaluated by the patient's self report, was present in all the infected people. Triceps skinfold percentage, which assesses arm fat accumulation, appeared lower in the PI group compared to the control group, suggesting that there is lipoatrophy in this area. There was no differences between groups in relation to lean body mass percentage obtained by MAMC adequacy or by BIA, which was not good enough to assess fat accumulation in some areas, because whole-body impedance is predominantly determined $(>90 \%)$ by the limbs impedance, even though the limbs contain less than $50 \%$ of the total body water (17), and because the electrical current mainly passes through the fat free mass, which is calculated by subtraction. Whole-body BIA does not assess regional body composition $(33,41)$, in contrast with anthropometric assessment. Since G2 presents higher IMC adequacy but it does not present higher BFP adequacy according to the sum of subscapular, bicipital, tricipital and suprailiac skinfold and it also shows lower arm fat according to TSF adequacy, it could be suggested that higher IMC was obtained by fat free mass, in this study presented by MAMC adequacy; on the other hand this was not observed either. There are two hypothesis left: that there is fat mass excess located in parts where the anthropometric assessment could not detect; or that these HIV-1 infected patients treated with $\mathrm{PI}$ weigh more as a consequence of higher body water concentration. The lower percentage of body fat observed in all the HIV-1 infected patients and the decreased TSF adequacy in the group treated with PI in relation to CG may suggest lipodystrophy in the upper limbs, especially in the group treated with PI. Patients receiving HAART treatment with PI had significantly lower viral loads, higher TG levels and low HDL levels. Moreover, some observations prompted the hypothesis that $\mathrm{PI}$ can determine an atherosclerotic damage of the vascular wall $(2,25)$. In this study, there were no differences between the groups in relation to lean body mass percentage obtained by anthropometric assessment or bioelectrical impedance, however the results 
obtained by antropometric assessment in the group treated with PI in relation to CG may suggest lipodystrophy in the upper limbs; therefore, further study is needed to investigate these parameters after a longer therapy period, because we believe there is a relationship between lipodystrophy and longer therapy duration, as it has been described recently (27). In addition, there is a need to explore the relationship between HAART and metabolic changes. In our study, we provide information about the clinical role of HAART with PI in HIV-1 infected individuals and the possible association with lipodystrophy.

\section{ABNORMAL FAT DISTRIBUTION AND USE OF PROTEASE INHIBITORS}

All patients gave their written informed consent and the study was approved by the Ethics Research Committee of São Paulo State University, UNESP, Botucatu Campus, OF.031/2001-CEP, MVCR/asc.

\section{REFERENCES}

1 ALLAIN CC., POON LS., CHAN CSG., RICHMOND W., FU PC. Enzymatic determination of total serum cholesterol. Clin. Chem., 1974, 20, 470-5.

2 BEHRENS G., SHMIDT H., MEYER D., STOLL M., SCHMIDT RE. Vascular complications associated with use of HIV protease inhibitors. Lancet, 1998, 351,1958.

3 BERNASCONI E., CAROTA A., MAGENTA L., PONS M., RUSSOTTI M., MOCCETTI T. Metabolic changes in HIV-infected patients treated with protease inhibitors. AIDS, 1998, 12, 88.

4 BONNET E., CUZIN L., SAILlER L., OBADIA M., MARCHOU B., CARON P., MASSIP P. Associated lipodystrophy metabolic disorders due to protease inhibitor containing regimens. In: WORLD AIDS CONFERENCE, 12, Geneva, 1998. Abstracts... Geneva, 1998. Abstracts 12299.

5 BOUFASSA F., DULIOUST A., LASCAUX AS., MEYER L., BOUE F., DELFRAISSY JF., SOBEL A., GOUJARD C. Lipodystrophy in 685 HIV-1-treated patients: 
influence of antiretroviral treatment and immunovirological response. HIV Clin. Trials, 2001, 2, 339-45.

6 CARR A. HIV Protease Inhibitor- Related Lipodystrophy Syndrome. Clin. Infect. Dis., 2000, 30, S135-42.

7 CARR A., COOPER DA. Adverse effects of antiretroviral therapy. Lancet, 2000, 356, 1423-30.

8 CARR A., MILLER J., LAW M., COOPER, DA. A syndrome of lipoatrophy, lactic acidaemia and liver dysfunction associated with HIV nucleoside analogue therapy: contribution to protease inhibitor-related lipodystrophy syndrome. AIDS, 2000, 14, 25-32.

9 CARR A., SAMARAS K., BURTON S., LAW M., FREUND J., CHISHOLM DJ., COOPER DA. A syndrome of peripheral lipodistrophy, hyperlipidaemia and insulin resistance in patients receiving HIV protease inhibitors. AIDS, 1998, 12, F51-8.

10 CARR A., SAMARAS K., CHISHOLM DJ., COOPER A. Buffalo hump in HIV. Lancet, 1998, 351,1736.

11 CARR A., SAMARAS K., THORISDOTTIR A., KAUFMANN GR., CHISHOLM DJ., COOPER DA. Diagnosis, prediction, and natural course of HIV-1 protease inhibitor-associated lipodystrophy, hyperlipidemia, and diabetes mellitus: a cohort study. Lancet, 1999, 353, 2093-9.

12 CRONK CE., ROCHE AF. Race and sex-specific reference data for triceps and subscapular skinfolds and weight/stature. Am. J. Clin.Nutr., 1982, 35, 347-54.

13 DOUMAS BT., WALTSON W., BIGGS HG. Albumin standards and the measurement of serum albumin with bromocresol green. Clin. Chim. Acta, 1971, 31, 87-96.

14 DURNIN JV., WOMERSLEY J. Body fat assessed from total body density and its stimulation from skinfold thickness: measurements on 481 men and women aged from 16 to 72 years. Br. J. Nutr., 1974, 32, 77-97.

15 FERRINI MT., PASTERNAK J., WAITZBERG DL. Síndrome da imunodeficiência adquirida (Aids). In: WAITZBERG DL. 2 ed. Nutrição enteral e parenteral na prática clínica. Rio de Janeiro: Atheneu, 1995 : 407-15.

16 FISHER LD., BELLE GV. Biostatistics: a methodology for the health sciences. New York: Wiley Interscience, 1993. 991p. 
17 FOSTER KR., LUKASKI HC. Whole-body impedance-what does it measure? Am. J. Clin. Nutr., 1996, 64, 388S-96.

18 FOSSATI P., PRENCIPE L. Serum triglycerides determined colorimetrically with an enzyme that produces hydrogen peroxide. Clin. Chem., 1982, 28, 2077-80.

19 FRISANCHO AR. New standards of weight and body composition by frame size and height for assessment of nutritional status of adults and elderly. Am. J. Clin. Nutr., 1980, 40, 808-19.

20 FRISANCHO AR. Anthropometric standards for the assessment of growth and nutritional status. Ann Arbor: University of Michigan Press, 1990. 189p.

21 GERRIOR J., KANTAROS J., COAKLEY E., ALBRECHT M., WANKE C. The fat redistribution syndrome in patients infected with HIV: measurements of body shape abnormalities. J. Am. Diet. Assoc., 2001, 101, 1175-80.

22 GRUNFELD C. Disturbances in lipid metabolism due to HIV infection and its therapy. In: CONFERENCE ON RETROVIRUSES AND OPPORTUNISTIC INFECTIONS, 6, Chicago, 1999. Proceedings... Chicago, 1999. Session 7, S3.

23 JOHNSTON S. Nutrition related to HIV-1-AIDS infection. Rev. Enferm., 1998, 21 , 71-8.

24 KOTLER DP., ROSENBAUM K., WANG J., PIERSON RN. Studies of body composition and fat distribution in HIV-infected and control subjects. J. Acquir. Immune Defic. Syndr. Hum. Retrovirol., 1999, 20, 228-37.

25 LAURENCE J. Vascular complications associated with use of HIV protease inhibitors. Lancet, 1998, 351, 1960.

26 LEDERGERBER B., EGger M., OPRAVIL M., TELENTI A., HIRSCHEL B., BATTEGAY M., VENAZZA P., SUDRE P., FLEPP M., FURRER M., FRANCIOLI P., WEBER R. Clinical progression and virological failure on highly active antiretroviral therapy in HIV-1 patients: a prospective cohort study. Lancet, 1999, 353, 863-8.

27 LICHTENSTEIN KA., WARD DJ., MOORMAN AC., DELANEY KM., YOUNG B., PALELLA JUNIOR FJ ., RHODES PH., WOOD KC., HOLMBERG SD. Clinical assessment of HIV-associated lipodystrophy in an ambulatory population. AIDS, 2001, 15, 1389-98. 
28 LO JC., MULLIGAN K., TAI VW., ALGREN H., SCHAMBELAN M. "Buffalo hump" in men with HIV-1 infection. Lancet, 1998, 351, 867-70.

29 MOOSER V., CARR A. Antiretroviral therapy-associated hyperlipidaemia in HIV-1 disease. Curr. Opin. Lipid., 2001, 3, 313-9.

30 PALELLA FJJ., DELANEY KM., MOORMAN AC., LOVELESS MO., FUHRER J., SATTEN GA., ASCHMAN DJ., HOLMBERG SD. Declining morbidity and mortality among patients with advanced human immunodeficiency virus infection. HIV outpatient study investigators. N. Engl. J. Med., 1998, 338, 853-60.

31 PEREIRA PCM., MEIRA DA., CURI PR., SOUZA N., BURINI RC. The malarial impact on nutritional status of Amazonian. Rev. Inst. Med. Trop., São Paulo, 1995, 37, 19-24.

32 PONTES LCR., TRINDADE EB., PEREIRA PCM., SOUZA ER. Perfil lipídico de indivíduos infectados pelo HIV tratados com ou sem inibidores de protease. Rev. Bras. Nutr. Clin., 2001, 16, S1-131.

33 PRIOR BM., CURETON KJ., MODLESKY CM., EVANS EM, SLONIGER MA, SAUNDERS M, LEWIS RD. In vivo validation of whole body composition estimates from dual-energy X-ray absorptiometry. J. Appl. Physiol., 1997, 83, 623-30.

34 SAINT-MARC T., PARTISANI M., POIZOT-MARTIN I., BRUNO F., ROUVIERE O., LANG JM., GASTAUT JA., TOURAINE JL. A syndrome of peripheral fat wasting (lipodystrophy) in patients receiving long-term nucleoside analogue therapy. AIDS, 1999, 13, 1659-67.

35 SceVola D., DI MATteo A., UBerti F., MinOIA G., POletti F., FAgA A. Reversal of cachexia in patients treated with potent antiretroviral therapy. AIDS Read., 2000, 10, 365-75.

36 SCHWENK A., BeISENHERZ A., KREMER G., DIEHL V., SALZBERGER B., FÄTKENHEUER G. Bioelectrical impedance analysis in HIV-infected patients treated with triple antiretroviral treatment. Am. J. Clin. Nutr., 1998, 70, 867-73.

37 SMITH CJ., LEVY I., SABIN CA., KAYA E., JOHNSON MA., LIPMAN MC. Cardiovascular disease risk factors and antiretroviral therapy in an HIV-positive UK population. HIV Med., 2004, 5, 88-92. 
38 THIÉBAUT R., DABIS F., MALVY D., JACQMIN-GADDA H., MERCIÉ P., VALENTIN VD. Serum triglycerides, HIV-1 infection, and highly active antiretroviral therapy, aquitaine cohort, France, 1996 to 1998. Groupe d'Epidemiologie Clinique du Sida en Aquitaine (GECSA). J. Acquir. Immune. Defic. Syndr., 2000, 23, 261-5.

39 VIRABEN R., AQUILINA C. Indinavir-associated lipodystrophy. AIDS, 1998, 12, 379.

40 WAITZBERG DL., FERRINI MT. Avaliação Nutricional. In: WAITZBERG DL. 2 ed. Nutrição enteral e perenteral na prática clínica. Rio de Janeiro: Atheneu, 1995:12752.

41 WANG J., KOTLER DP., RUSSELL M., BURASTERO S., MAZARIEGOS M., THORNTON J., DILMANIAN FA., PIERSON JUNIOR RN. Body-fat measurement in patients with acquired immunodeficiency syndrome: which method should be used? Am. J. Clin. Nutr., 1992, 56, 963-7.

42 WURTZ R. Buffalo hump in HIV. Lancet, 1998, 351, 1735-6. 